IZA DP No. 4613

Local Human Capital Externalities and Wages at the Firm Level: The Case of Italian Manufacturing

Massimiliano Bratti

Roberto Leombruni

December 2009 


\title{
Local Human Capital Externalities and Wages at the Firm Level: The Case of Italian Manufacturing
}

\author{
Massimiliano Bratti \\ University of Milan \\ and IZA \\ Roberto Leombruni \\ Universiy of Turin \\ and Laboratorio Revelli, Collegio Carlo Alberto
}

Discussion Paper No. 4613

December 2009

\author{
IZA \\ P.O. Box 7240 \\ 53072 Bonn \\ Germany \\ Phone: +49-228-3894-0 \\ Fax: +49-228-3894-180 \\ E-mail: iza@iza.org
}

Any opinions expressed here are those of the author(s) and not those of IZA. Research published in this series may include views on policy, but the institute itself takes no institutional policy positions.

The Institute for the Study of Labor (IZA) in Bonn is a local and virtual international research center and a place of communication between science, politics and business. IZA is an independent nonprofit organization supported by Deutsche Post Foundation. The center is associated with the University of Bonn and offers a stimulating research environment through its international network, workshops and conferences, data service, project support, research visits and doctoral program. IZA engages in (i) original and internationally competitive research in all fields of labor economics, (ii) development of policy concepts, and (iii) dissemination of research results and concepts to the interested public.

IZA Discussion Papers often represent preliminary work and are circulated to encourage discussion. Citation of such a paper should account for its provisional character. A revised version may be available directly from the author. 
IZA Discussion Paper No. 4613

December 2009

\section{ABSTRACT \\ Local Human Capital Externalities and Wages at the Firm Level: The Case of Italian Manufacturing}

We use a unique firm-level data set merging administrative information on average wages paid by firms by skill level (blue collars and white collars), Population Census information on the local stock of human capital available to firms and survey information on firm characteristics to investigate the existence and magnitude of local human capital externalities in Italian Manufacturing. The latter represents an interesting case study due to the prevalence of small family business and a technological lag with respect to the US, to which most evidence supporting local human capital spillovers refers. Our estimates show that in Italy, like in the US, firms located in geographical areas with a higher stock of human capital pay higher wages. This evidence is robust to many variants of the econometric specification and to addressing potential endogeneity issues using instrumental variables estimation and instruments based on the lagged expansion of the Italian higher education system and the lagged demographic structure.

JEL Classification: J24, J31, 120

Keywords: firm, local human capital externalities, Italy, manufacturing, wages

Corresponding author:

Massimiliano Bratti

DEAS

Università degli Studi di Milano

via Conservatorio 7

I-20122, Milan

Italy

E-mail: massimiliano.bratti@unimi.it

\footnotetext{
* We would like to thank participants to presentations given at the University of Bergamo, the University of Eastern Piedmont, the Laboratorio Revelli, the ITSG 2008, the ESPE 2009 and the EALE 2009 conferences, and people who gave comments on past versions of this paper, in particular Paolo Buonanno, David Card, Alberto Dalmazzo, Konstantinos Tatsiramos and Jan van Ours, for useful suggestions. The usual disclaimers apply.
} 


\section{Introduction and motivation}

Human capital investments have both private and social economic returns. While the idea that a worker's own human capital raises her/his labour income has now reached a wide level of consensus among economists, empirical research on the social returns to human capital, for instance on the effect of educated workers on non-educated workers' productivity and wages, is much scarcer and generally less conclusive.

In what follows we will restrict our attention to one specific form of human capital only: tertiary education. Tertiary education represents an interesting educational level to look at. Indeed, while for primary and secondary schooling there is almost universal support in all developed countries for strong government subsidization, in many countries there is a recent trend towards reducing government spending for tertiary education (e.g., in Italy) or to shift the burden of funding the Higher Education (HE) system away from the taxpayer and towards students and their families based on the idea that most benefits of $\mathrm{HE}$ are of a private nature (e.g., in the UK with the introduction of top-up fees, see Greenaway and Haynes 2003). However, in case positive externalities to HE do exist, reducing public support for HE could also have negative consequences for individuals without a university degree.

When it comes to studying human capital externalities, Italy represents an interesting case study, mainly for two reasons. Firstly, most empirical evidence supporting the existence of positive human capital externalities relates to the US, which is a country at the technological frontier. It would then be interesting to assess whether externalities also emerge for the countries and sectors that are late-comers in technological terms, such as Italian Manufacturing (Faini et al. 1999). Secondly, Italy is characterized by very low levels of individual and worker geographical mobility. A relevant feature of human capital is its 'geographical' or 'local' dimension: it is embodied in human beings and it can be transferred from one place to another only if they agree to move. As a consequence, some regions or countries may end up being human capital constrained. In this regard, assessing whether local communities benefit from the expansion of $\mathrm{HE}$ is also important to inform tertiary education policies. 'Local human capital policies', that is policies aiming at increasing local access to HE by favoring a wide diffusion of university premises within a country may be particularly important when mobility costs are high and the returns to education are relatively low, or not high enough to generate 
substantial mobility of graduates such as the case in Italy, as they might avoid low human capital traps. ${ }^{1}$

In this paper, we investigate human capital externalities using firm-level average wage data. The idea is that if externalities do exist in production, we should see firms located in geographical areas with higher levels of human capital having a higher productivity and paying higher average wages than otherwise similar firms located in areas with lower levels of human capital. For each firm, the local level of human capital is defined as the share of college educated workers among all workers in manufacturing in the province (NUTS 3) in which the firm is located.

We make a number of contributions to both the previous general literature on human capital externalities and the one specifically related to Italy. First, to the best of our knowledge, we are the first to match administrative data on wages from the Italian National Social Security Institute (Istituto Nazionale della Previdenza Sociale, INPS hereafter) with a widely used firm-level survey on Italian Manufacturing (the Unicredit's Survey on Italian Manufacturing Firms, SIMF hereafter). ${ }^{2}$ This offers two main advantages: 1) INPS administrative wage data are less likely to be subject to measurement errors compared to survey data; 2) INPS wage data are available by level of qualification (white collars and blue collars) while SIMF only provides firm average wage data. This enables us to address the potential issue of 'standard neoclassical supply effects' recently emphasized by Moretti (2004a) and Ciccone and Peri (2006) by estimating separate wage equations by skill level. ${ }^{3}$ Second, SIMF data allow us to control for many factors that are potentially correlated with both local human capital and wages (such as a firm's physical capital stock or R\&D activities) and that are generally not available in cross-section or longitudinal worker data (e.g., Moretti 2004a). This implies that studies using such data may suffer from an omitted variable problem and local human capital may capture the effect of firm unobserved local characteristics, as has been recently emphasized by Moretti (2004c), who uses firm-level data. ${ }^{4}$ Third, unlike studies using worker data, focusing

\footnotetext{
${ }^{1}$ For some examples of these policies see Currie and Moretti (2003) for the US or Andersson et al. (2004) for Sweden.

${ }^{2}$ Some recent papers using the same survey are, for instance, Parisi et al. (2006), Boeri and Garibaldi (2007) and Benfratello et al. (2008).

${ }^{3}$ In what follows we will use the words 'skill' and 'qualification' interchangeably.

${ }^{4}$ Dalmazzo and de Blasio (2007a;b), who use cross-section household survey data to estimate human capital spillovers on individual wages, try to tackle this problem by including
} 
on firm-level data that also provides information on the skill structure of the workforce within the firm enables us to test whether local human capital externalities emerge over and above spillovers potentially arising within a firm. This is important since previous work has shown that human capital spillovers could emerge within a firm (see, among others, Battu et al. 2003, Martins and Jin 2008). Therefore, if firm's own human capital is not properly controlled for in the wage equations, local human capital may simply act as a proxy for it (see Canton 2009). This also represents an improvement over Moretti (2004c) who does not have data on the firm's skill level and has to impute it using 3-digit industry-city cells from the US Census of Manufacturers. Last but not least, as we already said, unlike most of the previous literature that focuses on the US we investigate human capital externalities in an industry (Italian Manufacturing) that due to its structural characteristics (small family business, 'mature' products) cannot be considered as being at the frontier of technological progress and for which knowledge spillovers could be less important.

A central finding of our paper is that local human capital is positively related to average wages paid by Italian manufacturing firms, and that this relation is stronger for white-collar (i.e. skilled) workers. This evidence is robust to adding several covariates, which might account for a spurious correlation between local human capital and wages, in the wage equations. Even when we use ordinary least squares (OLS, henceforth), and the causal interpretation of our estimates may be questioned, several pieces of evidence suggest that the estimated effects are likely to capture knowledge spillovers: human capital externalities are indeed larger in firms where the main sources of knowledge and innovation are external to the firm, and are smaller and statistically insignificant when considering the share of college educated workers in the overall population or in the workforce rather than only in Manufacturing, like one would have expected if the source of the externality were mainly knowledge spillovers. When instrumental variables (IV, henceforth) estimation is used to address the potential problem of endogeneity of local human capital, using instruments based on the (presumably exogenous) lagged expansion of HE supply and lagged demographic structure, our estimates of local human capital spillovers remain statistically significant and are even larger in size with respect to OLS estimates.

The paper is organized as follows. Section 2 introduces a brief survey of

aggregated measures of local physical capital stock in the wage equation. 
the empirical evidence, both international and specifically relating to Italy. Section 3 describes the econometric model. Section 4 summarizes the main characteristics of the data set. Section 5 reports the empirical results and section 6 concludes.

\section{Past empirical evidence on human capital externalities}

In this section we report a short and non exhaustive survey of past empirical evidence focusing only on recent work investigating human capital externalities using micro-data. There are several potential sources of local human capital externalities. Moretti (2004b) mentions 'technological externalities' produced by technological increasing returns. As stated by Lucas (1988) the source of these kinds of externalities may be, for instance, the sharing of knowledge between workers or individuals. Externalities may also take a pecuniary form, not originating from assumptions about the production function but from market interactions like for instance in Acemoglu (1998): an increase in the supply of human capital could increase R\&D investment to introduce skill-complementary technologies and raise the productivity of skilled workers in the long-run (skill-bias technological change).

Externalities need not be positive, of course. Moretti (2004b) makes the example of the signaling model of education. Education could simply be a signal of an individual's productivity (ability). If the level of workers' education increases locally, employers might simply raise their hiring standards without any positive effect on productivity. In this case, the social returns to education would be negative: education becomes a social cost.

As stated by Moretti (2004b), there are different ways of testing for the presence of human capital externalities in production, by looking at wages, production or land prices. Due to data availability most researchers have used wages and we will do the same.

To date, the evidence on local human capital externalities is 'mixed'. Acemoglu and Angrist (2000) and Ciccone and Peri (2006) investigated local human capital externalities in the US and did not find any supporting evidence, while Moretti (2004a;c) for the US and Muravyev (2008) for Russia found statistically and economically significant local human capital externalities. Various factors have been identified as potentially responsible for this 
difference in results:

1. the proxy of human capital used. While Acemoglu and Angrist (2000) and Ciccone and Peri (2006) mainly focus on average years of education, Moretti (2004a;c) and Muravyev (2008) focus on tertiary education attainment. According to Moretti (2004a) the focus on higher education rather than on secondary or lower schooling levels is justified by the fact that the former is likely to produce market externalities (e.g., productivity growth) while the latter is likely to mainly produce non-market effects. The empirical evidence seems to support this claim;

2. the spatial unit considered. The specific choice of the spatial unit could make a difference since as Fu (2007) and Rosenthal and Strange (2008b) show the geographical spread of knowledge spillovers could be rather limited. This is intuitive if human capital externalities are produced by knowledge exchanges due to interactions among individuals or workers since a worker is more likely to interact with spatially closer individuals. Hence, focusing on smaller geographical units (e.g., cities or metropolitan areas rather than states) could help to identify local human capital externalities. In this respect, while Acemoglu and Angrist (2000) uses state-level data, all other studies use city-level (or Metropolitan Areas) data;

3. the instruments used. Some studies used IV techniques to identify the causal effect of local human capital. In this case, also the choice of instruments is likely to make a difference. For instance, as stressed by Duranton (2006), the instruments used by Acemoglu and Angrist (2000), i.e. child-labour and compulsory-schooling laws, are likely to have an effect especially on 'marginal students' and to affect lower schooling levels rather than higher education. Some of the instruments used by Moretti (2004a) or Muravyev (2008) are instead more likely to affect tertiary education achievement, such as the presence of a land-grant college for the former or pre-transition levels of tertiary educational achievement and the historical location of university establishments for the latter. This is important especially if externalities only emerge from university educated individuals.

To the best of our knowledge only two studies have addressed the issue of human capital externalities in Italy using micro-data, and both have consid- 
ered average years of education rather than tertiary educational achievement but contrary to US literature they have found a significant effect.

Dalmazzo and de Blasio (2007b) use Italian individual-level data from the Survey of Household Income and Wealth (SHIW) run by the Bank of Italy to study human capital externalities at the local labour market (LLM) level considering all economic sectors. LLM are similar in size to metropolitan areas. The authors use as a proxy of local human capital average years of schooling in the LLM population, taken from the 1991 Census. They both apply OLS and IV to repeated cross-sections from SHIW and find a significant positive effect of local human capital on individual wages. However, as emphasized by Moretti (2004a) the evidence of a positive effect of local human capital on average wages is not necessarily an indication of human capital externalities but may be produced by imperfect substitutability between skilled and unskilled workers. Then, Dalmazzo and de Blasio proceed to estimate separate wage regressions for low-skilled and high-skilled workers. The effect of local human capital on both wages is positive, only marginally statistically significant for skilled-workers and statistically significant and larger for unskilled workers, as predicted by theory in the case of imperfect skill substitutability. The authors take this as evidence in favour of positive human capital externalities. In a closely related paper using the same data, Dalmazzo and de Blasio (2007a) find similar results.

\section{Econometric model}

We adopt the Mincer approach by estimating a firm-level (log) wage regression by skill level augmented with an indicator of local human capital. In particular, we follow Moretti (2004a) and estimate the following wage equations for white collars (W) and blue collars (B), respectively:

$$
\begin{aligned}
& w_{i p W}=\alpha_{0}+\alpha_{1} K_{i}+\mathbf{T}_{\mathbf{i}}^{\prime} \boldsymbol{\alpha}_{\mathbf{2}}+\alpha_{3} F C S_{i}+\alpha_{4} L C S_{p}+\mathbf{X}_{\mathbf{i}}^{\prime} \boldsymbol{\alpha}_{\mathbf{5}}+u_{i W}+u_{p W}+\epsilon_{i W} \\
& w_{i p B}=\beta_{0}+\beta_{1} K_{i}+\mathbf{T}_{\mathbf{i}}^{\prime} \boldsymbol{\beta}_{\mathbf{2}}+\beta_{3} F C S_{i}+\beta_{4} L C S_{p}+\mathbf{X}_{\mathbf{i}}^{\prime} \boldsymbol{\beta}_{\mathbf{5}}+u_{i B}+u_{p B}+\epsilon_{i B}
\end{aligned}
$$

where $i$ is firm subscript, $p$ is the spatial subscript and $W, B$ are the skilllevel subscripts, respectively. ${ }^{5}$ We consider as the relevant spatial unit Italian

\footnotetext{
${ }^{5}$ Although the underlying theory has been developed for the perfectly competitive labour market case (see Moretti 2004a), in which the wage equals the worker's marginal productivity, the same specification can be used also in the case of imperfectly competitive
} 
provinces ${ }^{6}$ which are the administrative equivalent of US counties. We distinguish two levels of skills, blue collars and white collars. This distinction is due to the fact that earnings data come from the Italian National Social Security Institute's archives (see section 4), which does not collect information on workers' educational level but only on their level of qualification. $w_{i j s}$ is the firm-level nominal annual average wage for firm $i$, in province $j$ and for skill-level $s=W, B$ in natural logarithm (see Appendix II). We follow Acemoglu and Angrist (2000) and Moretti (2004a) and use nominal wages as our dependent variable. Indeed, as we are considering Manufacturing, a sector producing tradable goods, average productivity has to be higher in provinces where nominal wages are higher. ${ }^{7} K_{i}$ is the natural logarithm of physical capital intensity, that is the ratio between the real capital stock and the total number of workers. $\mathbf{T}_{\mathbf{i}}$ is a vector of technological indicators, $F C S_{i}$ is firm human capital proxied by firm college share (the share of university graduate workers on total firm employment) and $\mathbf{X}_{\mathbf{i}}$ a vector of other firmlevel controls. $L C S_{j}$ is the measure of local human capital, i.e. the local college share among manufacturing workers, and $\alpha_{4}$ is the main parameter of interest. We will interpret a statistically significant $\alpha_{4}>0$ as evidence

markets. In this case, it must be noted that with the augmented Mincer equations usually estimated in the literature, researchers are testing the joint hypothesis that there are localized human capital externalities in production (i.e. workers are more productive) and that workers receive a part of the productivity rise.

${ }^{6}$ In Italy in 2001 there were 20 regions (NUTS 2) and 103 provinces (NUTS 3). Since the data on local human capital is computed using the 2001 Population Census public use micro-file, which for privacy reasons does not include a municipality identifier for municipalities with less than 100,000 inhabitants, it is not possible to consider finer geographical disaggregations, such as municipalities or local labour market systems.

${ }^{7}$ In previous studies of local human capital externalities, some authors have controlled in the augmented Mincer equation for the average house rents by geographical area. However, following Roback $(1982 ; 1988)$, this variable is likely to be endogenous, since its equilibrium value is also affected by the local college share and by the presence of production externalities. The same endogeneity issue affects the local endowment of amenities, which is likely to be partly determined by the local human capital. Moreover, controlling for house rents or amenities in case local human capital has similar effects in terms of production and consumption externalities (cf. Dalmazzo and de Blasio 2007a) could generate the undesirable result that local human capital becomes insignificant in the wage equation, as it only captures the effect that is orthogonal to amenities. As shown by Dalmazzo and de Blasio (2007a) in case there are consumption externalities individuals may accept a lower wage in exchange of a higher life quality, and augmented Mincer equations may fail to detect production externalities. We will see that this is not our case. In section 5.1.2 we will also estimate a specification that allows to include province fixed effects, and to control in this way for potentially important province characteristics that have been omitted from our regressions. 
consistent with positive local human capital spillovers. In particular, given that we are controlling for firms' investment in physical capital, R\&D and ICT, $\alpha_{4}$ is likely to mainly capture non-pecuniary externalities, i.e. knowledge spillovers, rather than pecuniary ones. By contrast, a positive $\beta_{4}$ is not necessarily an indication of positive spillovers, since it might be generated by supply substitution effects in case of imperfect substitution of workers by skill level. ${ }^{8} \mathrm{~A}$ positive $\alpha_{3}$ in the white-collar wage equation is largely expected given that graduates are likely to be in white-collar occupations and that there are positive private returns to tertiary education in Italy. However, since we estimate a wage equation at the firm-level, $\alpha_{3}$ is likely to capture not only private returns but also within-firm social returns to higher education. A positive and significant $\beta_{3}$ in the wage equation for blue collars could be instead interpreted as evidence consistent with within-firm human capital spillovers, as blue collars are unlikely to have a university degree. $u_{s i}$ and $u_{s p}$ are firm-level or province-level unobservables, respectively, which may be correlated with the regressors included in each equation, and $\epsilon_{s i}$ is assumed to be white noise. A more detailed description of the variables used is available in Appendix I.

Moretti (2004a) carefully discusses the problem of endogeneity of local human capital. In particular, the problem is likely to be produced by the correlation between firm-level or province-level unobservable characteristics and local human capital. Examples of unobservables that might generate such correlation are, for instance, demand shocks to specific sectors or firms that may attract skilled workers to a given area and also raise workers' productivity (endogenous migration). Moretti (2004a) makes the example of San Jose in California following the internet boom that drove up demand for qualified workers, increased their wages and attracted highly educated workers to the area. This could also be seen as a problem of reverse causality in case of endogenous mobility, that is, one is likely to find a higher supply of human capital in areas where firms pay higher wages to highly educated workers. In this case OLS estimates would be biased upward. However, the bias needs not be necessarily positive. Indeed, since workers in Italian Manufacturing are often low skilled, high wages offered by local manufacturing firms raise the opportunity cost of university education, and may create a disincentive for investing in human capital. A classical example is that of

\footnotetext{
${ }^{8}$ As local human capital increases unskilled workers become relatively scarcer and their wage increases.
} 
the Veneto region, which is characterized by an industrial structure based on Manufacturing, and by low unemployment rates and high university drop-out rates (Di Pietro 2006). In this case, unobservable factors positively affecting local manufacturing firm productivity might be negatively correlated with the accumulation of local human capital and OLS estimates could be biased downward. As noted by Moretti (2004a), in general finding proxies for all possible unobservables is not a viable solution to the problem and an alternative is resorting to IV techniques. This poses, of course, the uneasy task of finding variables correlated with the local college share but not with average wages paid by firms.

In section 5, we will make an attempt to address the issue of endogeneity of local human capital using IV. ${ }^{9}$

As we said, our empirical specification offers some advantages with respect to both Moretti (2004a) and Dalmazzo and de Blasio (2007b), among others. Using firm-level data we are able to control for many firm-level characteristics that might simultaneously affect firm productivity and attract human capital locally (such as capital intensity or investments in R\&D or ICT). Moreover, our specification enables us to assess whether local human capital externalities emerge over and above firm-level skill spillovers. ${ }^{10}$

\section{Data}

We measure the local stock of human capital with the share of manufacturing workers with a tertiary degree at province level. ${ }^{11}$ Our choice deserves some comments. As we will include in the wage equations controls for firm physical capital stock and technological inputs, our local human capital variable is aimed at mainly capturing learning rather then pecuniary spillovers, that is those emerging from the exchange of work-related knowledge between

\footnotetext{
${ }^{9}$ It must be noted that like for previous studies other controls that we include in the righthand-side of equations (1)-(2), such as the firm college share or the capital stock, might be endogenous. Since finding suitable instruments which also address their endogeneity is unfeasible with our data, we will limit ourselves here to lag them, so that they will be at least predetermined with respect to the dependent variables and the error terms in the wage equations.

${ }^{10}$ This is also done in Moretti (2004c) that investigates local human capital spillovers by estimating establishment-level production functions in US Manufacturing.

${ }^{11}$ In particular, we consider as tertiary degrees university diplomas, university undergraduate and postgraduate degrees and non-university tertiary education.
} 
workers. For this reason we use as a proxy of local human capital the tertiary educational achievement only of workers in the Manufacturing sector. The idea is that work-related knowledge is more likely to be exchanged between workers, and to induce an increase in firm productivity the more the workers' job tasks are similar. ${ }^{12}$ For this reason, we prefer to compute a sector-specific measure of local human capital. ${ }^{13}$ We use the public use microdata file of the 2001 Italian Population Census released by the Italian National Statistical Institute (ISTAT) gathering information on a representative sample of $1,117,928$ individuals, $2 \%$ of the total Italian population in 2001. The share of university educated workers in Manufacturing by province is computed using sample weights that expand the sample to the whole Italian population (see Appendix I). ${ }^{14}$ The college share in Manufacturing varies across Italian provinces. The average share in our sample is 0.05 , with a maximum of 0.13 for the province of Rome (Italy's capital) and a minimum of 0.02 for the province of Lecce (Puglia region, Southern Italy). The average share of college educated workers employed by Manufacturing firms in the estimation sample is equally low, and amounts to only 0.04 . The average share of white collars over total firm employment in the sample is instead 0.26. Hence, college educated workers only account for a small minority of white-collar employees in Manufacturing firms.

'Wage' data are gathered by INPS. In particular, the data refer to firms' average annual wages by skill-level for full-time workers (blue collars and white collars). These data have both advantages and disadvantages. The main advantage is that they come from an administrative source and are less likely to be affected by measurement errors compared to the self-declared survey data normally used in individual-level studies. The main disadvantage is that, unlike those studies, we are unable to compute a measure of hourly wage since INPS does not collect information on working hours. ${ }^{15}$ Hence,

\footnotetext{
$\overline{12}$ This idea is not new in economics and dates back to Marshall (1890). Also Moretti (2004c) recently shows that human capital spillovers are stronger among 'economically close' sectors.

${ }^{13}$ Previous studies have considered a variety of definitions of local human capital. Dalmazzo and de Blasio (2007b;a) and Muravyev (2008) focus on the whole population, Acemoglu and Angrist (2000), Moretti (2004a) and Ciccone and Peri (2006) focus on all workers and Moretti (2004c) on workers in Manufacturing only.

${ }^{14}$ Like most of the empirical literature on the topic, we focus in this paper on spillovers that arise from the share of college graduates, although spillovers may also arise from the number and the density of graduates.

${ }^{15}$ This often happens also with administrative data from other countries (cf. Dustmann
} 
despite our measure of average annual earnings being adjusted for part-time work in terms of days (see Appendix II), the variable mixes information on hourly wages with the one on hours worked. For instance, a higher local stock of human capital might induce higher competition for promotions among college educated workers and a higher effort among white collars, e.g. longer working hours (cf. Rosenthal and Strange 2008a). This would cause some problems for the interpretation of our estimates since in this case an increase in annual labour earnings that is produced by an increase in working hours could be wrongly ascribed to a rise in hourly productivity (i.e. hourly wage). We will address this and other issues in Section 5.1.2. ${ }^{16}$

Firm data come from SIMF, currently managed by the Unicredit banking group (formerly by Mediocredito and later by Capitalia). The survey collects information on a sample of manufacturing firms with 11-500 employees and on all firms with more than 500 employees. The SIMF has been repeated over time at three-year intervals since 1991 and in each wave a part of the sample is fixed while the other part is completely renewed every time (see Capitalia 2002, p. 39). This helps to analyse both variations over time for the firms observed in different waves (panel section) and the structural changes of the Italian economy, for the part of the sample varying in each wave. Like many other surveys used in the empirical literature, also SIMF is not representative of micro-firms. The data set gathers a wealth of information on: balance sheet data integrated with information on the structure of the workforce and governance aspects; R\&D expenditures and ICT; international activities (e.g., export, FDI flows); information on financial structure and strategies. Information about the educational level of the firm's workforce, that is the firm's college share that we include as a control in equations (1) and (2), is reported only for the final year in each wave. Given that we can be confident about our measure of local human capital only for 2001, the year of the Census, while we do not have good measures of local human capital for other years, we limit our analysis to 2001. In particular, we merge the 8th wave of SIMF with 2001 Census data and INPS data for $2001 .{ }^{17}$ In the empirical analysis we analyze wages in 2001 (INPS) by relating them to local

et al. 2009, for Germany).

${ }^{16}$ However, this problem is likely to be more relevant for blue collars than for white collars, since for the latter overtime work is usually unpaid.

${ }^{17}$ The merging procedure between SIMF and INPS data was made under a confidentiality agreement at the INPS Head Office (Rome). See Appendix II for more detailed information. 
human capital in 2001 (Population Census) and to lagged firm-level variables referring to 1998-2000 coming from the 8th SIMF's wave.

\section{Results}

In this section we report the main results of the empirical analysis by distinguishing between the econometric specifications using OLS and the ones using IV.

\subsection{OLS estimates}

\subsubsection{Main results}

Tables 2 and 3 report the OLS estimates using as dependent variable firms' (log) average wages for white collars and blue collars, respectively. Since our primary focus is on human capital spillovers, we report only the coefficients on local human capital and some other regressors of particular interest. In both tables, each column progressively adds controls to address potential issues of endogeneity of local human capital or firm college share, which might be generated by province-level or firm-level omitted variables. The specifications with the same column number in the two tables include the same covariates.

Column (1) includes the local human capital stock measured as the share of workers with a university degree in Manufacturing at province-level. The coefficients on local human capital are positive and statistically significant at the $5 \%$ level in both wage equations. A one percent point (p.p., hereafter) increase in the share of workers in Manufacturing with a university degree in the province is associated with a 1.4 percent and a 1 percent increase in the wages of white collars and blue collars, respectively.

The coefficient on local human capital in column (1) cannot be interpreted as an indicator of local human capital spillovers since firms in provinces with a larger share of college educated workers in Manufacturing will also be more likely to hire university graduates. Hence, this coefficient is likely to partly capture the effect of the firm's college share. For this reason in column (2) we add the firm-level college share, i.e. the share of workers with a university degree employed in the firm. We also add as a further control the share of workers with upper secondary schooling working within the firm. The 
coefficients on local human capital remain positive but are slightly reduced in size in both wage equations and continue to be statistically significant at the $5 \%$ level. Increasing by one p.p. local human capital is now associated to an increase in white collars' wages of 1.3 percent and blue collars' wages of 0.9 percent. The effects of a one p.p. increase in the firm's college share on wages are 0.34 percent and 0.09 percent, for white collars and blue collars, respectively. The effects of a one p.p. increase in the secondary school ratio is instead associated to a 0.03 and a 0.05 percent increase in white collars and blue collars wages, respectively. The results on the two firm skill ratios go in the expected direction: the firm college share is statistically significant and larger in the white-collar equation, while the secondary school ratio is significant and larger in the blue-collar equation. Indeed, while the skills acquired in upper secondary schooling, especially in vocational tracks, are likely to raise especially blue collars' productivity, the skills aquired at university are likely to raise white collars' productivity.

In order to clean out the effects of human capital from other local characteristics, which might simultaneously affect firm productivity and education of the workforce, column (3) includes region fixed effects, province-level male unemployment rates in the population aged 15-24 and a dummy for the presence of university campuses in the province in 2000. Unemployment is likely to impact negatively on wages and positively on local human capital accumulation (due to lower opportunity costs of education), while the presence of university campuses within the province might produce positive spin-offs with firms and have a positive effect both on local human capital and wages. Region fixed effects capture other region-level unobservables. By including region fixed effects the effect of local human capital is now identified by between-province variation within regions. The main consequence of including such controls is to reduce the size of the coefficient on local human capital in both wage equations. The effects of a one p.p. increase in local human capital go down to 1 percent for white collars and to 0.8 percent for blue collars, and are both statistically significant at the $1 \%$ level.

Given the potential complementarity between human capital and other forms of capital, a possible source of correlation between education and wages is that firms located in areas in which there are relatively more university graduates, or that hire relatively more graduates, might also invest more in physical and technological capital (pecuniary externalities). An alternative hypothesis is that causality might go exactly in the opposite direction, firms 
investing more in advanced technologies might also require better educated workers. In order to control for these potential effects, column (4) includes firm (log) physical capital intensity as an additional regressor. The effects of local human capital rise and go up to 1.1 percent and 0.9 percent for white collars and blue collars, respectively. Column (5) adds some indicators of technological capital, namely $R \& D$ intensity (i.e. the ratio between R\&D workers and total employment), a dummy for having invested in ICT and a dummy for R\&D cooperation with universities. Including proxies of technological capital has no appreciable effect neither on the coefficient on local human capital nor on that on the firm college share with respect to the previous specification. From column (5) the elasticities of white collar's and blue collar's wages to the physical capital stock are 0.032 and 0.021 , respectively. Technological inputs are not significant in both equations. Hence, our results show that, unlike for the US, for a relatively laggard country in terms of research and technology such as Italy, higher firm investments in physical and technological capital cannot be considered as the main channel through which local human capital spillovers take place, at least in Manufacturing (cf. Iranzo and Peri 2009).

Probably the stock of physical capital and the proxies of the technological level that we included do not fully capture all the heterogeneity existing across different industries. We know from the rich literature on inter-industry wage differentials that firms in some industries consistently pay higher wages and hire more educated workers (see Katz and Summers 1989). Alternatively, firms operating in those industries may be more likely to locate in areas where human capital is abundant. To test these hypotheses we include in column (6) dummies for 2-digit ATECO industries (see Appendix I). The coefficients on local human capital are reduced in size. One p.p. increase in the fraction of college graduates working in Manufacturing is associated to a 0.7 percent increase in wages of white collars and to a 0.4 percent increase in the wages of blue collars. The coefficient on local human capital remains statistically significant at the $5 \%$ level only in the white-collar equation.

As we already said, the inter-industry wage differentials literature has emphasized that firms' market power might allow them to pay rents to their workers, and that this might attract high ability or better educated workers. Along with industries (which may be more or less exposed to competition) another proxy of a firm's market power may be its size, which is then added in column (7). The results are robust and very similar to those in the previous 
column. The coefficient on firm size is positive and significant in both wage equations.

Column (8) adds some controls for other potential determinants of firm productivity and demand for human capital: export status and FDI flows. Indeed, the trade literature has emphasized the skill-bias of trade in developed countries, and the potential positive correlation between firm wages and a firm's internationalization modes (see, for instance Bernard and Jensen 1995; 1997). The results remain quantitatively and qualitatively similar. An increase of one p.p. in the fraction of college educated workers at the province level is associated to a 0.7 percent increase in white collars' wages and to a 0.4 percent increase in blue collar's wages. The last effect is statistically significant only at the $10 \%$ level. Both exporting and FDI flows are positively and significantly associated with white collars' wages while the former is negatively associated with blue collars' wages.

Summarizing, we find a positive association between local human capital and both white collars' wages and blue collar's wages. However, while the former correlation remains statistically significant also after controlling for many covariates that might account for such an association, the latter looses statistical significance at $5 \%$ in our most general specification. As stressed in section 3 these overall results could be interpreted as evidence in favour of positive province-level human capital spillovers. The order of magnitude of the local human capital spillovers we estimate with OLS is a bit smaller than that found by Moretti (2004a;c) for the US and by Muravyev (2008) for Russia, which can be explained by the fact that, as we said, in our specification we are likely to estimate only localized human capital non-pecuniary externalities.

The different effect of local human capital on wages by skill level and the strongest impact exerted on skilled workers can be explained in the light of the wage-setting mechanism prevailing in Italy. In Italy there are three potential levels of wage bargaining: 1) industry national level; 2) firm level; 3) individual level. However, industry level bargaining is responsible for the largest part of workers' wages. This is particularly true for unskilled workers, for whom individual wage bargaining is extremely rare. Casadio (2008) reports that for blue collars the percentage of wage above the minimum collectively bargained by unions at the industry level amounts on average to $5.3 \%$ for firms between 20 and 49 employees, and to $11.6 \%$ for those with more than 500 employees. The corresponding figures for white collars are 
$7.8 \%$ and $20.3 \%$. As a consequence blue collars' wages could be unresponsive to local or firm level conditions. Pistoresi and Strozzi (2003) find, for instance, that in the metal-mechanic industry, where firm-level agreements are more frequent, the centralized level of wage negotiations generates rent sharing, while decentralized wage bargaining does not lead to any degree of rent sharing between unions and employers. ${ }^{18}$

\subsubsection{Robustness checks and further analysis}

In this section we investigate the robustness of our results to a number of changes made to the econometric specification of the wage equations. We use as a baseline specification the one estimated in column (8) of Tables 2 and 3 , which we will refer to as our "baseline" specification. All these robustness checks are reported in Table 4.

Working hours. We already anticipated in section 4 that since we do not have data on working hours, our estimates of the externalities could capture the combined effect of local human capital on both working hours and hourly wage. For this reason, we used the 2001 Italian labour force survey data to create province-sector-skill cells and computed the average number of weekly working hours. We used 12 2-digit ATECO sectors for Manufacturing. ${ }^{19}$ Weekly working hours were added to the baseline specification in column (8) in Tables 2 and 3 and the estimates are reported in model (1) in Table 4. It is possible to note that including the number of working hours does not produce any significant change to our estimates.

Workers' characteristics. Using firm-level data does not allow us to control for some workers' characteristics that are likely to be correlated with wages, and potentially also with local human capital. We used the 2001 Work Histories Italian Panel (WHIP) data to compute statistics for average

\footnotetext{
${ }^{18}$ This result is in line with the literature showing that in countries characterized by a high degree of decentralization of the wage bargaining system there is a strong link between wages and firm or industry profitability. See, among the others, Blanchflower et al. (1996) and Hildreth and Oswarld (1997).

${ }^{19} \mathrm{DF}, \mathrm{DG}$ and DH industries were aggregated. ATECO codes for Manufacturing are: DA (food products, beverages and tobacco), DB (textiles and textile products), DC (leather and leather products), DD (wood and wood products), DE (pulp, paper and paper products; publishing and printing), DF (coke, refined petroleum products and nuclear fuel), DG (chemicals, chemical products and man-made fibres), DH (rubber and plastic products), DI ( non-metallic mineral products), DJ (basic metals and fabricated metal products), DK (machinery and equipment), DL (electrical and optical equipment), DM (transport equipment), DN (other manufacturing).
} 
workers' experience and seniority (in months) and the percentage of female workers by province-sector-skill cells and province-size-skill cells for manufacturing firms. ${ }^{20}$ Due to empty or small cell size problems, it was not possible to compute such statistics for province-sector-size-skill cells. Because of the same issue, we had to consider only three broad categories for firm size (11-100, 101-500, more than 500) while we considered all the 14 two-digit ATECO sectors for Manufacturing. Model (2) shows no noticeable change when experience, seniority and the percentage of female workers, matched by firm sector, are included in the regressions. By contrast, model (3) shows that when the same variables are matched by firm size the coefficient on local human capital looses statistical significance in the blue-collar equation while the estimate for the white-collar equation is robust. Model (3) and (4) control for working hours, experience, seniority and the percentage of female workers matched in the two different ways. The results for the whitecollar equation are very robust while model (4) shows a reduction in the significance and magnitude of the coefficient on local human capital in the blue-collar equation.

Differential effect of local human capital and province-level unobservables. Since our measure of local human capital is at province level, there is always the fear that some other local factors correlated with local human capital, which are not captured by region fixed effects, could drive our results. To address this issue, we use a strategy similar to the one used by Rajan and Zingales (1998) and Guiso et al. (2004), among others. If we make an assumption on which firms are more likely to benefit from local human capital externalities, then we can test whether ceteris paribus those firms perform better if they are located in provinces with a higher stock of local human capital, after controlling for fixed local characteristics (i.e. province fixed effects). We implement this strategy by considering the differential effect of local human capital on firms with different Pavitt sectors. ${ }^{21}$ We divided Pavitt sectors among those where the main source of knowledge and innovation is internal $R \& D$ (Scale-intensive and Science-based) and those where the main sources of innovation are not based on firm's internal R\&D (Sup-

${ }^{20}$ For a description of the WHIP data set see Contini et al. (2009). We used WHIP since the information on firm size was not publicly released in the 2001 Italian labour force survey data.

${ }^{21}$ Pavitt's taxonomy categorizes industrial firms along trajectories of technological change according to sources of technology, requirements of the users, and appropriability regime (Pavitt 1984). 
plier dominated and Specialised Supplier) but are external. The idea is that while in the former worker knowledge is mostly produced internally, is specific to the firm and can be hardly transferred among firms, in the latter, since knowledge can be more easily transferred among firms, a firm's workers are more likely to benefit from the knowledge of workers locally employed by other firms. We tested this hypothesis in model (6) by including in the base specification an interaction term between local human capital and a dummy indicator for firms classified as Supplier dominated or Specialised Supplier. In line with our theoretical predictions, the coefficient on local human capital is larger in Scale-intensive and Science-based sectors for white collars, while the effect on blue collar's wages is not statistically different among the two types of firms.

Human capital externalities vs. other 'local' effects. In general it is difficult to separately identify human capital externalities from agglomeration effects. This is due to the fact tha human capital externalities could account for a substantial part of agglomeration economies (see Rosenthal and Strange 2008b). For this reason we did not include the province population in our regressions, since this would cause over-controlling. Indeed, when we take some proxies of agglomeration effects commonly used in the literature, such as the population mass in the province for urbanization effects (urban agglomerations) or the number of manufacturing workers in the province for localization effects (cf. Rosenthal and Strange 2004), the correlation coefficients with local human capital are very high. The high correlation is likely to create multicollinearity problems. This is indeed confirmed by the fact that when both population (or number of manufacturing workers) and local human capital are jointly included in the white-collar equation they are statistically insignificant, while both population (or number of manufacturing workers) and local human capital are significant when they are included separately. The same happens for the blue-collar wage equation. Hence, although in model (6) we show that our estimates of human capital externalities are generally robust to including province fixed effects (which partly control for agglomeration effects if they work in the same way on all firms irrespective of the Pavitt sector), one might still believe that the coefficient on local human capital in our basic specification may be capturing the effect of other province-level factors that have nothing to do with the transfer of knowledge among workers. If this were the case we should find that other proxies of local human capital, such as the share of workers in all sectors with a university 
degree or the share of university educated population, should have similar effects on the wage of white collars and blue collars to the share of graduate workers in Manufacturing. In model (7) we use as a proxy of local human capital the share of all workers with a university degree, while in model (8) we use the share of university educated population. These two alternative measures of local human capital turn out to be statistically insignificant and their coefficients are remarkably lower in magnitude. We interpret this evidence as consistent with the fact that local human capital in our basic specification is likely to be capturing learning externalities rather than other forms of agglomeration externalities or province-level effects, since knowledge transfer is likely to be larger among workers working in the same industry (i.e. Manufacturing) and performing therefore similar tasks. ${ }^{22}$

Firm size. We use firm-level data and we do not have establishment data. This means that we might be wrongly attributing local human capital to firms, since local human capital was attributed to them by considering the location of the head quarter. For this reason, in model (9) we run our estimations in two separate samples including small firms ( $\leq 50$ employees), which are unlikely to be multi-unit, and large firms (>50 employees). Our estimates show a positive correlation between local human capital and whitecollar wages for both categories of firms, while the positive correlation between blue-collar wages and local human capital turns out to be statistically significant only for larger firms.

Graduate quality. Although, as we will argue in Section 5.2, the geographical mobility of Italian graduates is quite limited and on average we don't expect graduates to be of better quality where the college share is higher, endogenous mobility cannot be completely ruled out, especially for South to North migrations. ${ }^{23}$ In the case of endogenous migration a positive coefficient on local human capital may capture a better average quality of graduates employed by firms located in areas where the college share is higher. A way to address this issue is by allowing the coefficients on firm level college and

${ }^{22}$ This evidence is not necessarily in contrast with Dalmazzo and de Blasio (2007a) who considering the years of education in the whole population find a positive effect on individual wages. Firstly, they consider the whole economy, not only the Manufacturing sector. Secondly, since their specification does not include firm-level covariates, which are not available in SHIW, their estimates of human capital externalities also capture pecuniary externalities.

${ }^{23}$ Actually, the correlation may be of the opposite sign, the average quality of graduates may fall in provinces where the expansion of $\mathrm{HE}$ is higher if one focuses only on the local production (and not import) of graduates, see the following point. 
secondary school shares to vary across provinces (see, Moretti 2004c). The estimates in model (10) show that allowing heterogeneity in the effect of firm human capital on average wages has no appreciable effect on the coefficient on local human capital for white collar workers.

Nonlinearities. As a last robustness check we explored the potential existence of nonlinearities in the effect of local human capital. There are several reasons to expect possible nonlinearities in the effect of local human capital. The first one is that uneducated workers might learn more than proportionally with the increase of the college share, for instance because it becomes simpler to meet (and interact with) college graduates. That is the relation between local human capital and wages might be increasing and convex. Alternatively, it might be the case that above a given threshold, a further increase in the college share does not produce any further increase in productivity, since there are already many university graduates from whom non-graduates can learn, that is the relation may be increasing and concave. We observe that given the quite low percentage of university graduates in Manufacturing, the first hypothesis is more credible for Italy. Another potential source of nonlinear effects might be a quantity-quality trade-off for university graduates. As HE expands and the college share increases, one might expect graduates to be increasingly drawn from the bottom part of the ability distribution, that is graduates may be of a lower average quality (see Carneiro and Lee 2009). In this case, the spillovers of local human capital may fall after the college share reaches a given threshold. However, this is not necessarily true, if the HE expansion mainly benefits able but credit constrained individuals. We investigate potential nonlinearities in the effect of local human capital by including a quadratic function in college share in the wage equations and by allowing different slopes for provinces with college share above and below the sample median (0.0488), respectively. ${ }^{24}$ Model (11) reports the result of the first exercise. The two coefficients of the quadratic function are never statistically significant, due to the high correlation between the linear and the quadratic terms in local college share (0.98 in both the white-collar and the blue-collar samples). By contrast, the results for model (12) show that the slope of the average firm wage-local human capital relationship is increasing in local college share: the effect above the median is almost $80 \%$ higher than the one below the median. Although, due to the

\footnotetext{
${ }^{24}$ We used the median of the white-collar sample for both white-collar and blue-collar samples. In the blue-collar sample the median is slightly lower (0.0481).
} 
limited variation in the college share, we are not able to further explore potential nonlinearities in the effect of local human capital, we simply observe that the results obtained from a specification linear in the college share may understate the real magnitude of local human capital spillovers.

\subsection{Instrumental variables estimates}

Although we made an effort to include many covariates which if omitted may produce a correlation between local human capital and the error terms in the wage equations, we cannot be absolutely sure that some other relevant factors have not been omitted from the wage equations and that there might still be an endogeneity problem. A possible way to address this problem and to identify the causal effect of local human capital on average wages at the firm-level is using IV methods.

Before discussing our identification strategy we would like to make a point. The problem of reverse causality of local human capital with productivity and wages, that is the fact that graduates could migrate towards provinces where firms pay higher wages, is likely to be less severe for Italy than for other countries where graduates are very mobile, such as the US (Bound et al. 2004). This is the case since individual geographical mobility is relatively low in Italy compared to other developed countries (Cannari et al. 2000). Di Addario and Patacchini (2008), for instance, maintain that non-pecuniary benefits from residence (social networks, friendship) and substantial mobility costs related to travel and housing are likely to be responsible for the low workers' geographical mobility in Italy. This means that the ability of firms to attract human capital from other provinces is generally limited and that human capital must be produced locally. However, a possible endogeneity problem might also be caused by individuals in provinces with a higher expected future demand for graduates, and higher expected future wages, enrolling more frequently in HE. In this regard, we note that local production of human capital is a lengthy process ${ }^{25}$ and individuals are often unable to make correct long-term predictions on wages when enrolling in $\mathrm{HE}^{26}$ Secondly, a very small minority of Italian university graduates finds

\footnotetext{
${ }^{25}$ The legal duration of most university degrees in Italy was 4-5 years in the period under study, although actual duration was much longer.

${ }^{26}$ Dominitz and Manski (1996) and Betts (1996), for instance, cast serious doubts on students' ability to correctly predict earnings. These studies generally show a large heterogeneity in students' expectations about actual earnings, which reflect a large variation
} 
employment in Manufacturing, most of them working in the Service sector, and therefore it is extremely unlikely that individuals base their educational decisions on their expecta

It must be noted that also the issue where more productive firms may tend to move where there is more local human capital is not particularly relevant for the Italian case. Michelacci and Silva (2007) using the Bank of Italy's Survey of Household Income and Wealth (SHIW) data for 1991-1995 show for instance that in Italy about $79 \%$ of entrepreneurs established firms in the same province where they were born.

Despite these facts, we cannot exclude of course that local human capital is endogenous, and for this reason we make use of IV estimation.

To identify the causal effect of local human capital using IV we need to find some variables affecting the current stock of local human capital in Manufacturing, as we defined it, but that are uncorrelated with the average wages currently paid by manufacturing firms. Hence, we need something specifically related to Manufacturing. To build such instruments we proceed as follows. First, we identify graduates who are more likely to be employed in manufacturing firms. They are typically graduates in technical and science degrees (engineering, chemistry, and mathematical, physics and natural sciences) or hard social sciences degrees (economics, business and economics, banking, statistics). We define these as "manufacturing-related" fields. Using the Italian Ministry of Education University and Research (MIUR) data on university supply we computed the number of manufacturing-related university degree courses in 1990 and 1995 and their density per 10 square km in each province (by dividing the course supply by the province surface in 10 square $\mathrm{km}$ ). Then, we computed the change in manufacturing-related courses density by province between 1990 and 1995, which we define $\Delta U N I V$ and that represents our first instrument. ${ }^{27}$ We consider the change in supply instead of the lagged value of course density in 1990, since by time differencing course density we are likely to purge out any time-invarying province-level unobservable characteristic affecting university supply that might also be correlated with current wage levels (i.e. the error terms in the wage equations). This is important as we use instruments varying at the province level and

in students' information.

${ }^{27}$ The choice of 1990 is determined by data availability. Indeed, from MIUR we have detailed information on university supply by province and faculty only starting from that year. We choose 1995 as the final year since, as we said, during the 90s the legal duration of most degrees was 4 or 5 years. 
cannot control for province fixed effects. There were large differences in the change of university supply across provinces. For instance, in our estimation sample for white collars, in which not all provinces are represented, the change in the density (per 10 square $\mathrm{km}$ ) of manufacturing-related degree courses ranges between -0.02 (Pesaro province, located in Central Italy) and 2.88 (Trieste province, located in North-Eastern Italy). Since the increase of local supply of manufacturing-related courses does not necessarily predict per se an increase in the college share in manufacturing, we use as a second instrument its interaction with the fraction of the population aged 5-14 in 1982, which is a proxy of the potential demand for HE that is induced only by demographic factors. Individuals aged 5-14 in 1982 are those who were the most likely to enter university during 1990-1995, the period which our variable of supply expansion refers to. ${ }^{28}$ An advantage offered by this second instrument is that by interacting the change in local university supply with the lagged demographic structure in the province, it will mainly capture the local production of graduates and help to address potential issues of endogenous migration of college educated workers towards high-productivity (i.e. wage) provinces. ${ }^{29}$ In order to control for other forms of university spillovers, we include among the covariates a dummy for the presence of a manufacturing-related faculty (as defined above) in the province in 2000.

In practice, we exploit differences in past province-specific HE education policies, in terms of HE supply expansion, to identify the effect of the local college share. ${ }^{30}$ Our idea is to use something that shifts the supply curve of HE but not the demand for HE. One potential threat to our identification strategy could be caused by the non-random lagged (between 11 and 6 years) expansion of the HE supply across provinces with respect to manufacturing firms' productivity in 2001. The Italian university system was subject to an intense process of reform during the 90s, which made it easier for HE institutions to open new campuses or faculties and create new degree courses with respect to the past. Indeed, before the reforms, the opening of new universities or faculties and the creation of new degrees required a law to be approved

\footnotetext{
${ }^{28}$ The typical ages at entry into HE in Italy was in the period under study, and still is, 18-19.

${ }^{29}$ Unless such forward-looking migration took place 20 years earlier. In any case, due to the age group we consider (5-14), residence is likely to have been decided not directly by the individuals but by their parents.

${ }^{30}$ A similar identification strategy is used by Fortin (2006) who estimates the effect of own-cohort relative supply on college wage premia for US states.
} 
by the Italian Parliament, which was no longer necessary after the reform. ${ }^{31}$ This generated a fast and sizeable expansion in the number of courses and university premises in Italy that can be considered as random with respect to manufacturing firms' productivity. Indeed, the increase in HE supply was not driven by an economic motive: the new university infrastructures did not follow the potential unfilled demand for HE, and cost-benefit analyses were never performed. Rather, the increase followed an indiscriminate allocation of public funds across the Italian regions, as acknowledged by the Italian Ministry of Education, University and Research (MIUR 1997). ${ }^{32}$

\footnotetext{
${ }^{31}$ Here we report the main steps of the 90 s reform of the Italian HE. A substantial reform of the functioning of universities (in terms of management, hiring, teaching loads) came in 1980 (Law n. 382, 11th July 1980), which established that any variation in the existing university supply should be included in a development plan (piani triennali), to be approved by the Minister of Education every three years (Law n. 590, 14th August 1982). Openings of new universities, Faculties or degree courses required a specific law to be passed by Parliament. It was a decade later that the requirement of parliamentary approval was abandoned (Law n. 341, 19th December 1990), whereas the inclusion in a development plan subject to ministerial approval was still retained. However, universities gained autonomy to advance proposals for new initiatives to the Ministry of Education. Up to that moment, a university professor was appointed to a chair corresponding to a specific course and in order to introduce a specific degree a university had to fulfill the requirement of a specific law listing the number and names of courses (i.e., exams) needed to attain the degree. This was also the rationale for the legal value of a degree across the country: as the teaching was in principle identical across the country, there was no reason to presume that identical degrees obtained in different universities could be different, given a centrally organized hiring procedure for professors through national competitions. Thus, in order to offer a new degree (to be selected from a closed list of admissible degrees) a university needed an almost complete new faculty corresponding to the courses to be taught. Some autonomy in setting student fees was granted with the budget law of 1993 (Law n. 537, 24th December 1993), in conjunction with a reduction of funding from the government. Universities were allowed to manage their teaching and research activities, but the creation of new courses was still subject to ministerial approval. In addition, professors' salaries and new hirings were still set and managed by the central government. This produced a 'soft budget constraint' as the bulk of the financing needs remained covered by the central government (from the universities' point of view, expanding the supply of courses was also a way of applying additional pressure on the government to hire new professors). The process of progressive devolution was completed in 1998, when universities were allowed to open (or close) new Faculties and/or courses without central approval, conditional on self-financing of the initiative (Presidential decree n. 25, 27th January 1998, issued in application of a general trend to devolution required by Law n. 59 15th Mach 1997, also known as legge Bassanini).

${ }^{32}$ From MIUR (1997): ' $\ldots$ the development of the new teaching supply does not appear to have followed a logic of territorial planning of the university premises taking into account the local flows of demand for HE (that is verifying the real size of students' demand), the potential labour market outcomes (professional needs of the country) and the existing
} 
Another factor that might cause our instruments to fail could be the endogeneity of the age structure with respect to local unobservable determinants of manufacturing firm productivity. This would happen in our case if: i) individuals who were predicting in 1982 a larger future increase in manufacturing firm productivity in certain provinces moved to these provinces and had at the same time a larger number of 5-14 aged children; ii) if individuals decided to have a higher number of children in view of a larger expected future increase in manufacturing firm productivity and that their fertility timing generated a higher proportion of 5-14 years old population in 1982. We think that given the fact that we lag demographic structure by 20 years and that we focus on a very specific age group ${ }^{33}$ (5-14 aged population) the occurrence of all such circumstances is rather unlikely and we are fairly confident that our instrument can be considered exogenous. Since the lagged demographic structure might be related to the age and experience of manufacturing workers in 2001, we use as baseline specifications for IV estimation the models (4) and (5) in Table 4, which control for working hours, workers' experience and seniority and the percentage of female workers.

Table 5 shows the results of our IV estimation. We report the estimates obtained for each skill level using the two instruments separately (just identified models), and those obtained from the overidentified model using both instruments, which also allows us to perform an overidentification test (Hansen J statistic). We report the results both when worker's experience, seniority and the percentage of female workers are matched by firm sector (see section 5.1.2) and when the same variables are matched by firm size, in columns (1)-(2) for white collars and (5)-(6) for blue collars.

For white collars, IV diagnostics show the relevance of the instruments, and their validity in the overidentified models. The spillover estimates range between 1.3 percent and 1.6 percent. By contrast, as we already saw in

infrastructures. In substance, there was no punctual evaluation of the initiatives, neither in absolute terms nor in comparative terms with respect to the compatibility with the whole HE system. In practice, the criterion of geographic rebalancing of university premises was privileged with the aim of closing the geographical gap between the supply and the demand of HE, neglecting the real entity of such demand ... but also the importance of the transport system, the receptive capacity of the student population and the financial help available to students to access the university premises.' (p. 3-4, our translation).

${ }^{33}$ Indeed, this would require individuals to not only change their reproductive behaviour in terms of the quantity of children but also a fine tune in terms of fertility timing for the age group 5-14 to be affected. 
section 5.1.2, the IV estimates show evidence of a positive effect of the college share on blue-collar wages, which is not necessarily indicative of a spillover, only when workers' controls are matched by province-sector-skill cells.

In columns (3)-(4) for white collars and (7)-(8) for blue collars, as a further robustness check, we reported the results of the IV estimates using as instruments the level of manufacturing-related course density per square $\mathrm{Km}$ in 1990 and its interaction with the 5-14 population in 1982. These instruments have the advantage of being more lagged in time than the ones already used, but they could be affected by time-invariant province-level unobservables. The estimates are very similar to those we already commented.

Overall, IV estimates are qualitatively and quantitatively consistent with the OLS results.

\section{Concluding remarks}

The idea that local human capital could produce positive production externalities is both old and appealing but the empirical evidence on local human capital spillovers is still 'mixed'.

The emergence and magnitude of human capital externalities are probably country and sector specific. In particular, positive externalities could be more likely to emerge in countries and sectors specializing in complex technologies and hi-tech products ('knowledge economies' or hi-tech sectors) compared to countries and industries specialized in traditional sectors and unskilledintensive products like Italy.

In this paper, we use a unique cross-section data set combining firms' balance sheet and survey data, Census data on local human capital and administrative data on earnings to investigate the presence of human capital spillovers in Italian Manufacturing. In particular we focus on spillovers originating from the share of graduate workers in Manufacturing at province level, and we investigate whether firms located in provinces with a larger college share paid higher wages in 2001 (the year of the Italian Census) than otherwise similar firms located in provinces with a smaller stock of human capital.

Using OLS we find that even after controlling for a variety of firm and local characteristics, there is a robust positive correlation between average wages paid by firms, especially to white collars, and local human capital. Although the possibility that unobserved province heterogeneity may partly 
explain these effects cannot be completely ruled out, we provide several pieces of evidence suggesting that the effects we estimated are likely to reflect local knowledge spillovers. Indeed, when we allow for the effect of local human capital to vary by technological type of sector according to Pavitt's taxonomy, and control for province fixed effects, the estimates remain positive and statistically significant. Moreover, the effect of local human capital on wages is larger in sectors where the main sources of knowledge are outside the firm. We also show that unlike the college share in Manufacturing, the college share in the population and in the workforce have much smaller positive effects on average wages in Manufacturing and are never statistically significant. This is what one would predict if our estimates were capturing knowledge spillovers, as the transmission of productivity-enhancing knowledge is more likely to take place among employees working in the same sector, and performing similar tasks.

In order to address the issue of potential endogeneity of local human capital with respect to productivity and wages, we use an IV strategy. We propose as instruments the lagged change (1990-1995) in the university supply of manufacturing-related degree courses, i.e. degree courses whose graduates are more likely to find employment in Manufacturing, and its interaction with 20-year lagged demographic structure. We argue that the expansion of HE supply that took place in Italy during 1990-1995 was both sizeable, thanks to a reform that eased both the opening of new campuses and of new degree courses by HE institutions, and presumably exogenous. Our IV estimates are qualitatively consistent with the OLS estimates, although somewhat larger in magnitude.

Our analysis shows overall that positive human capital spillovers also exist in relatively less technologically advanced countries compared to the US such as Italy.

What are the policy implications of our analysis? Firstly, the existence of substantial positive production externalities suggests that the burden of HE should not be completely moved towards university students and their families, since this might produce a sub-optimal investment in higher education, and that tertiary education expenditures should be partly financed by the general taxation. Secondly, from an efficiency point of view is not clear whether it would be optimal for a country's economic growth to concentrate the supply of HE to a limited number of HE institutions instead of spreading it geographically, like what has happened in Italy in the last two decades, 
since our analysis suggested the potential existence of nonlinearities in the effect of local human capital. However, from an equity point of view our findings suggest that policies of geographical concentration of the HE supply would be likely to exacerbate the geographical differences in productivity and wages, unless sufficient measures are taken to substantially raise both workers' and students' geographical mobility, in particular from Northern to Southern Italy. 


\section{Appendix}

\section{Appendix I. Variables description}

Wages. Firm average wages data by skill level, our dependent variable, come from the Italian National Social Security Institute's administrative archives. They are full-time adjusted average earnings by skill-level (white collars and blue collars) of all workers employed by the firm in Euros. For more details see Appendix II. Data refers to 2001. The variable is included in natural logarithm.

Local college share. It is the share of manufacturing workers with tertiary education who are resident in the province (NUTS 3) in which the firm is located, computed using the public use microdata file of 2001 Italian Census (ISTAT). In the Census residents are those individuals who usually live in the province even if at the date of the Census they were temporarily absent.

Population share with college education. It is the share of population with tertiary education in the province computed using the public use microdata file of 2001 Italian Census.

Worker share with college education. It is the share of all workers with tertiary education in the province computed using the public use microdata file of 2001 Italian Census.

Firm college share. It is the share of workers within the firm with a tertiary education. Data refer to 2000 and come from the 8 th wave of SIMF (see section 4).

Firm (upper) secondary school share. It is the share of workers within the firm with an upper secondary education. Data refer to 2000 and come from the 8th wave of SIMF (see section 4).

Male unemployment rate 15-24. It is the province male unemployment rate among men aged 15-24 in 2001 (source: ISTAT). We consider the youth unemployment rate since it is less likely to be affected by the local college share and men because they are more likely to work in Manufacturing.

College province 2000. It is a dummy that takes value one if a college was present in the province in 2000 (source: Italian Ministry of Education University and Research - MIUR).

RED cooperation with university. It is a dummy that takes value one if the firm did cooperate with a university in $R \& D$ in 2000 , information available from the 8th wave of SIMF. 
Capital intensity. It is the real physical capital stock per worker in thousands of Euros. The nominal capital stock is derived from balance sheet data and is evaluated at the net 'historical cost', that is the cost originally borne by the firm to buy the good reduced by the depreciation measured according to the relevant fiscal law (Fondo di ammortamento), which accounts for obsolescence and use of the good. The real capital stock is obtained using capital stock deflators provided by the ISTAT (cf. Moretti 2004c). All variables are deflated with the appropriate three-digit production price index (ISTAT). Data refer to 2000 and come from the 8 th wave of SIMF. The variable is included in natural logarithm.

$R \& D$ intensity. It is the ratio between $\mathrm{R} \& \mathrm{D}$ workers and the total number of workers within the firm. Data refer to 2000 and come from the 9 th wave of SIMF.

ICT investment. It is a dummy that takes on value one if the firm performed ICT investments in 1998-2000 and zero otherwise (see section 4). Data come from the 8 th wave of SIMF.

Export. It is a dummy that takes value one if the firm exported in 2000 and zero otherwise. Data come from the 8th wave of SIMF.

FDI. It is a dummy that takes value one if the firm undertook FDI flows in 2000 and zero otherwise. Data come from the 8th wave of SIMF.

Change in university course density (1990-1995). It is the change in manufacturing-related university courses' density at the province level between 1990 and 1995. See Section 5.2 for further details on how the variable was built (source: MIUR).

Population 5-14 ratio in 1982. It is the ratio of 5-14 years old among the whole population in 1982 at the province level. (source: ISTAT).

Manufacturing college. It is a dummy that takes on value one if a technical (engineering, chemistry, and mathematical, physics and natural sciences) or hard social sciences (economics, business and economics, banking, statistics) faculty was present in the province in 2000 (source: MIUR).

Average workers' weekly working hours. It is computed from the Italian 2001 labour force survey data (ISTAT), and is matched with SIMF by province-sector-skill cells. For more details see Section 5.1.2

Average workers' experience (months). It is computed from WHIP (INPS) and is matched with SIMF either by province-sector-skill or by province-sizeskill cells. For more details see Section 5.1.2

Average workers' seniority (months). It is computed from WHIP (INPS) 
and is matched with SIMF either by province-sector-skill or by province-sizeskill cells. For more details see Section 5.1.2.

Percentage of female workers. It is computed from WHIP (INPS) and is matched with SIMF either by province-sector-skill or by province-size-skill cells. For more details see Section 5.1.2.

Sector dummies. 2-digit ATECO sector dummies. ATECO stands for Classificazione delle attività economiche, that is an Italian classification of economic activities (i.e. industries) similar to the NACE European classification. Data come from the 8 th wave of SIMF.

Region dummies. Region (NUTS 2) dummies. In Italy there are 20 regions. Data come from the 8th wave of SIMF.

\section{Appendix II. Earnings data and INPS-SIMF match}

\section{i. Matching procedure}

To perform the analyses in this paper we linked together two different firmlevel data archives: the Osservatorio sulle Imprese, occupati dipendenti del settore privato non agricolo e retribuzioni medie annue di operai ed impiegati (Observatory on firms, non-agricultural private sector employees and yearly average earnings of blue collars and white collars) built from INPS' administrative archives with SIMF.

The Osservatorio is built upon the compulsory contributions forms collected by INPS from all private Italian firms with at least one employee on a monthly basis. It includes high quality data on employment size and earnings broken down by skill level (manual and non manual workers, cadre and managers, apprentices), plus information on the sector of activity, firm's birth and closure dates.

We linked the INPS' data (covering the years from 1997 to 2002), to the 8th wave of SIMF (covering the years from 1998 to 2000) using the fiscal ID number as a linkage key. Probably due to clerical errors in the maintenance of both archives the match was not perfect, but link failures remained below $2 \%$ of SIMF data. Since firm province is used to impute local human capital to firms, in case of discordance between SIMF and INPS data we used the province in SIMF that was built by using the municipality in which the firm was located. 


\section{ii. Average annual wage data}

Since the 1990-1994 edition of the Osservatorio the computation of employees' average earnings has been done by adjusting firms' total monthly wage bill to the maximum number of working days in a month (26), in the following way:

$$
M r m_{i}=\frac{M r_{i}}{G r_{i}} \times 26 \times d_{i}
$$

where:

$M_{r} m_{i}$ : total wage bill share of month $i$ for a full-month;

$M r_{i}$ : actual monthly wage bill share for month $i$;

$G r_{i}$ : actual number of working days in month $i$;

$d_{i}$ : average number of employees in month $i$.

For part-time white collars and blue collars the total number of working days is obtained by dividing by 6.66 the total number of hours indicated in INPS form DM10 (40 weekly hours divided in 6 days). Wages also include employer's social contributions, withholding income tax, sick pay, paid overtime work, Christmas bonus, back payments.

Further details are available (in Italian) at:

http://servizi.inps.it/banchedatistatistiche/menu/imprese/main.html 


\section{References}

Acemoglu, D., 1998. Why do new technologies complement skills? Directed technical change and wage inequality. Quarterly Journal of Economics 113(4), 1055-1089.

Acemoglu, D., Angrist, J., 2000. How large are human capital externalities? Evidence from compulsory schooling laws. NBER Macroeconomic Annual 15, 9-59.

Andersson, R., Quigley, J. M., Wilhelmson, M., 2004. University decentralization as regional policy: The Swedish experiment. Journal of Economic Geography 4(4), 371-388.

Battu, H., Belfield, C. R., Sloane, P. J., 2003. Human Capital Spillovers within the Workplace: Evidence for Great Britain. Oxford Bulletin of Economics \& Statistics 65(5), 575-594.

Benfratello, L., Schiantarelli, F., Sembenelli, A., 2008. Banks and innovation: Microeconometric evidence on Italian firms. Journal of Financial Economics 90(2), 197-217.

Bernard, A., Jensen, J., 1995. Exporters, jobs, and wages in U.S. manufacturing: 1976-1987. Brookings Papers on Economic Activity. Microeconomics , 67-119.

Bernard, A., Jensen, J. B., 1997. Exporters, skill upgrading, and the wage gap. Journal of International Economics 42(1-2), 3-31.

Betts, J. R., 1996. What do students know about wages? Evidence from a survey of undergraduates. Journal of Human Resources 31(1), 27-56.

Blanchflower, D., Oswald, A., Sanfey, P., 1996. Wage, profits and rentsharing. Quartely Journal of Economics 111(1), 227-251.

Boeri, T., Garibaldi, P., 2007. Two tier reforms of employment protection: A honeymoon effect? The Economic Journal 117(521), F357-F385.

Bound, H., Groen, J., Kézdi, G., Turner, S., 2004. Trade in university training: Cross-state variation in the production and stock of college-educated labor. Journal of Econometrics 121(1-2), 143-173. 
Cannari, L., Nucci, F., Sestito, P., 2000. Geographic labor mobility and the cost of housing: Evidence from italy. Applied Economics 32(14), 18991906.

Canton, E., 2009. Human capital externalities and proximity: evidence from repeated cross-sectional data. De Economist 157(1), 79-105.

Capitalia, 2002. Ottavo rapporto sull'industria italiana e sulla politica industriale, Tech. rep., Capitalia, Rome.

Carneiro, P., Lee, S., 2009. Trends in quality-adjusted skill premia in the United States, 1960-2000. CEMMAP Working Paper CWP02/09 .

Casadio, P., 2008. Ruolo e prospettive della contrattazione aziendale integrativa: informazioni dall'indagine della banca d'Italia. Paper presented at the 2008 meeting of the Italian Labour Economists Association .

Ciccone, A., Peri, G., 2006. Identifying human capital externalities: Theory with applications. Review of Economic Studies 73(2), 381-412.

Contini, B., Leombruni, R., Pacelli, L., Villosio, C., 2009. Wage Mobility and Dynamics in Italy in the 90s, in: Edward P. Lazear and Kathryn L. Shaw (Ed.), The Structure of Wages. An International Comparison, The University of Chicago Press, Chicago.

Currie, J., Moretti, E., 2003. Mother's education and the intergenerational transmission of human capital: Evidence from college openings. Quarterly Journal of Economics 118(4), 1495-1532.

Dalmazzo, A., de Blasio, G., 2007a. Production and consumption externalities of human capital: An empirical study for Italy. Journal of Population Economics 20(2), 359-382.

Dalmazzo, A., de Blasio, G., 2007b. Social returns to education in Italian local labor markets. Annals of Regional Science 41(1), 51-69.

Di Addario, S., Patacchini, E., 2008. Wages and the city. Evidence from Italy. Labour Economics 15(5), 1040-1061.

Di Pietro, G., 2006. Regional labour market conditions and university dropout rates: Evidence from Italy. Regional Studies 40(6), 617-630. 
Dominitz, J., Manski, C. F., 1996. Eliciting student expectations of the returns to schooling. Journal of Human Resources 31(1), 1-26.

Duranton, G., 2006. Human capital externalities in cities: Identification and policy issues, in: Arnott, R., McMillen, D. (Eds.), A Companion to Urban Economics, Blackwell Publishing Ltd., Oxford.

Dustmann, C., Ludsteck, J., Schoenberg, U., 2009. Revisiting the german wage structure. forthcoming in Quarterly Journal of Economics .

Faini, R., Falzoni, A. M., Galeotti, M., Helg, R., Turrini, A., 1999. Importing jobs and exporting firms? On the wage and employment implications of Italian trade and foreign direct investment flows. Giornale degli Economisti 58(1), 95-135.

Fortin, N. M., 2006. Higher-education policies and the college wage premium: Cross-state evidence from the 1990s. American Economic Review 96(4), 959-987.

Fu, S., 2007. Smart café cities: Testing human capital externalities in the Boston metropolitan area. Journal of Urban Economics 61(1), 86-111.

Greenaway, D., Haynes, M., 2003. Funding higher education in the UK: The role of fees and loans. Economic Journal 113(485), F150-F166.

Guiso, L., Sapienza, P., Zingales, L., 2004. Does local financial development matter? Quarterly Journal of Economics 119(3), 929-969.

Hildreth, A., Oswarld, A., 1997. Rent-sharing and wages: evidence from company and establishment data. Journal of Labor Economics 15(2), 318337.

Iranzo, S., Peri, G., 2009. Schooling Externalities, Technology and Productivity: Theory and Evidence from U.S. States. Review of Economics and Statistics 91(2), 420-431.

Katz, L. F., Summers, L. H., 1989. Industry rents: Evidence and implications. Brookings Papers on Economic Activity, Microeconomics , 209-275.

Lucas, R. J., 1988. On the mechanics of economic development. Journal of Monetary Economics 22(1), 3-42. 
Marshall, A., 1890. Principles of Economics, Macmillan.

Martins, P. S., Jin, J. Y., 2008. Firm-level social returns to education. Journal of Population Economics, on line first.

Michelacci, C., Silva, O., 2007. Why so many local entrepreneurs? Review of Economics and Statistics 89(4), 615-633.

MIUR, 1997. Verifica dei Piani di Sviluppo dell'Università 1986-90 e 1991-93, Ministero dell'Istruzione, dell'Università e della Ricerca, Rome.

Moretti, E., 2004a. Estimating the social return to higher education: Evidence from longitudinal and repeated cross-sectional data. Journal of Econometrics 121(1-2), 175- 212.

Moretti, E., 2004b. Human capital externalities in cities, in: Elsevier (Ed.), Handbook of Regional and Urban Economics, Elsevier, vol. 4, chap. 51, 1st ed., pp. 2243-2291.

Moretti, E., 2004c. Workers' education, spillovers, and productivity: Evidence from plant-level production functions. American Economic Review $94(3), 656-690$.

Muravyev, A., 2008. Human capital externalities. Evidence from the transition economy of Russia. Economics of Transition 16(3), 415-443.

Parisi, M. L., Schiantarelli, F., Sembenelli, A., 2006. Productivity, innovation and R\&D: Micro evidence from Italy. European Economic Review 50(8), 2037-2061.

Pavitt, K., 1984. Sectoral patterns of technical change: Towards a taxonomy and a theory. Research Policy 13(6), 343-373.

Pistoresi, B., Strozzi, C., 2003. Rent sharing and bargaining levels: Evidence from Italy. Giornale degli Economisti e Annali di Economia 62(2), 145-170.

Rajan, R., Zingales, Z., 1998. Financial dependence and growth. American Economic Review 88(3), 559-586.

Roback, J., 1982. Wages, rents and the quality of life. Journal of Political Economy 90(6), 1257-1278. 
Roback, J., 1988. Wages, rents and amenities: differences among workers and regions. Economic Inquiry 26(1), 23-41.

Rosenthal, S. S., Strange, W. C., 2004. Evidence on the nature and sources of agglomeration economies, in: Henderson, J., Thisse, J. (Eds.), Handbook of Regional and Urban Economics, Elsevier, Amsterdam, vol. 4.

Rosenthal, S. S., Strange, W. C., 2008a. Agglomeration and hours worked. Review of Economics and Statistics 90(1), 105-118.

Rosenthal, S. S., Strange, W. C., 2008b. The attenuation of human capital spillovers. Journal of Urban Economics 64(2), 373-389. 
Tables 


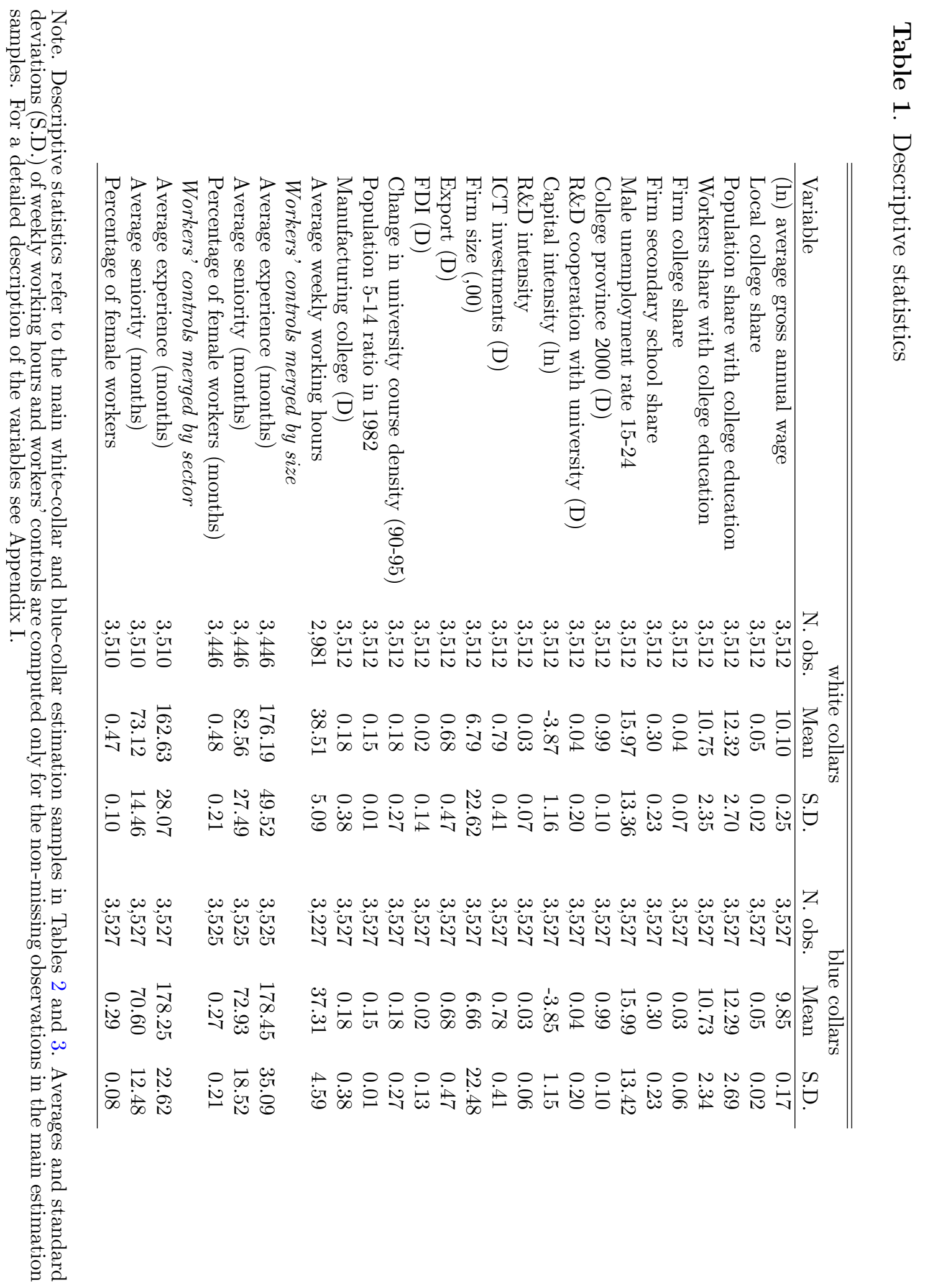




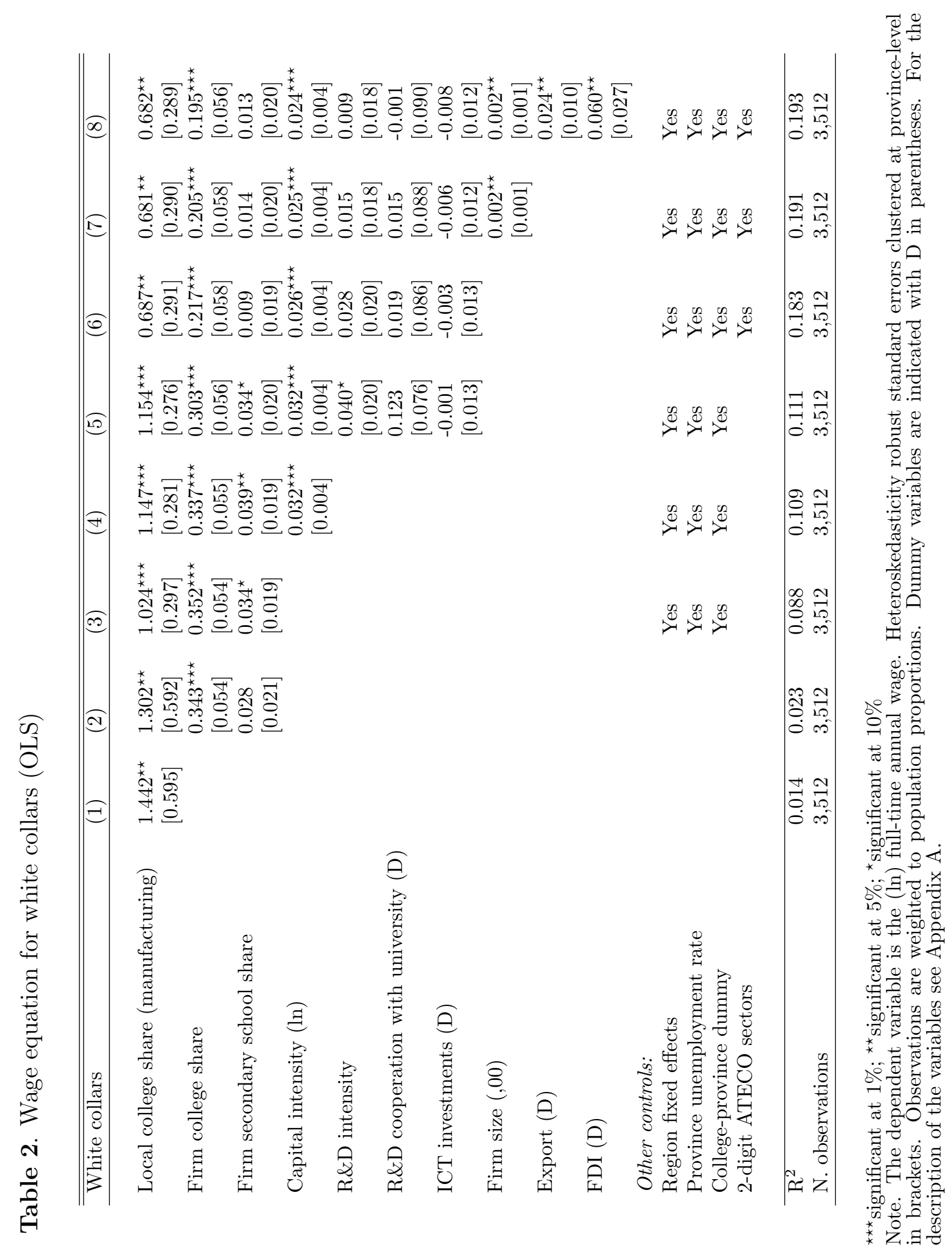




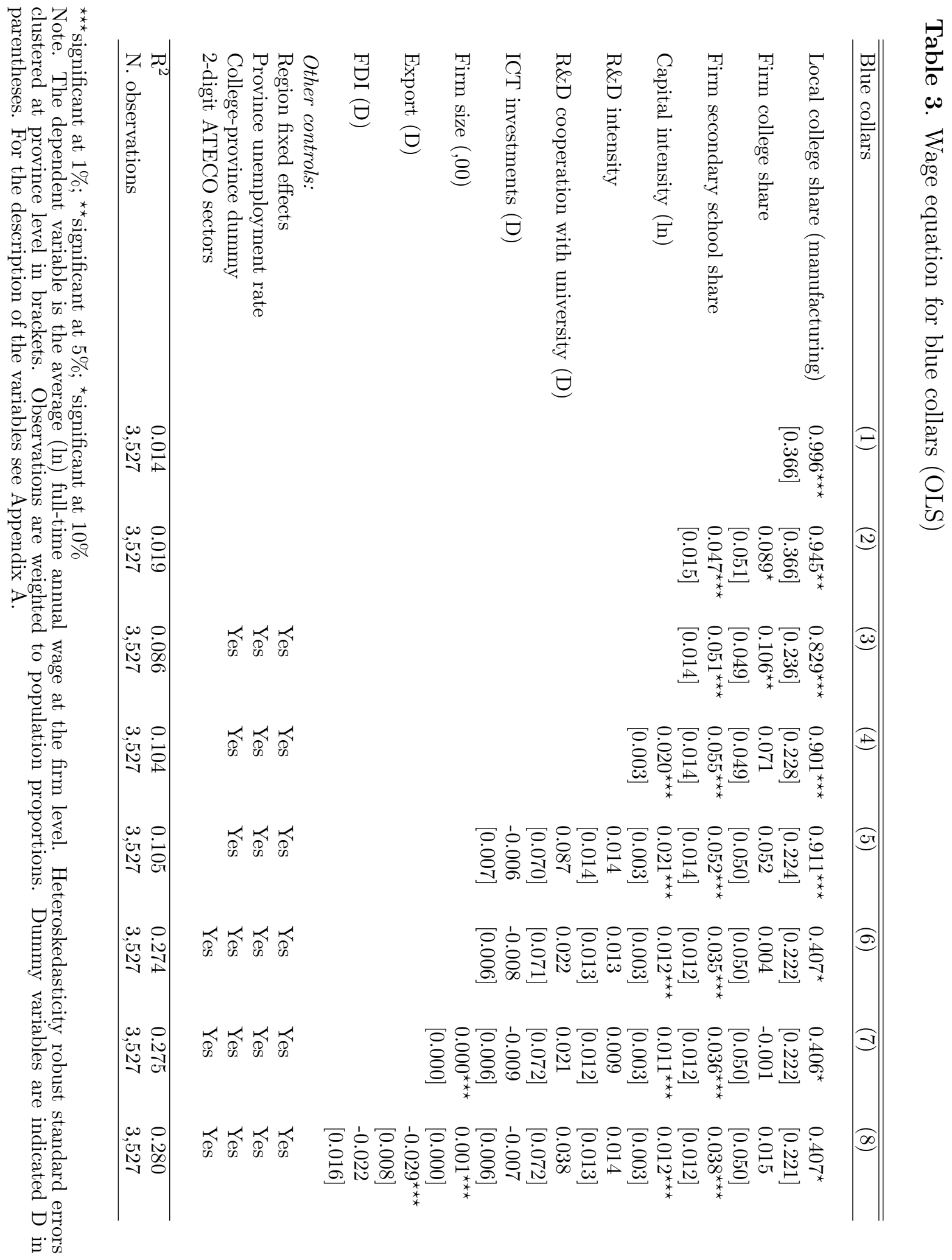




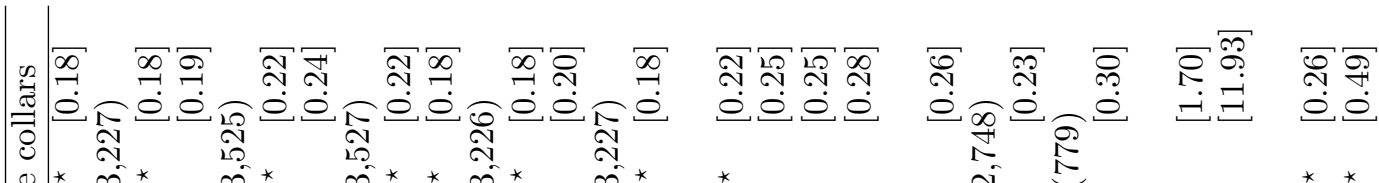

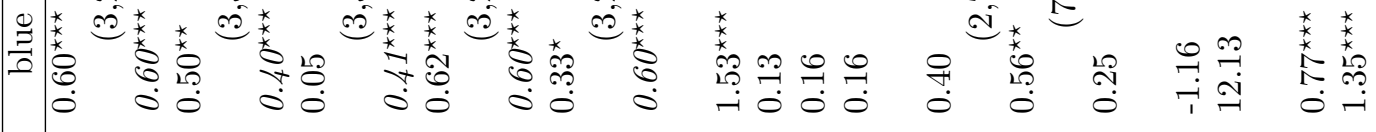

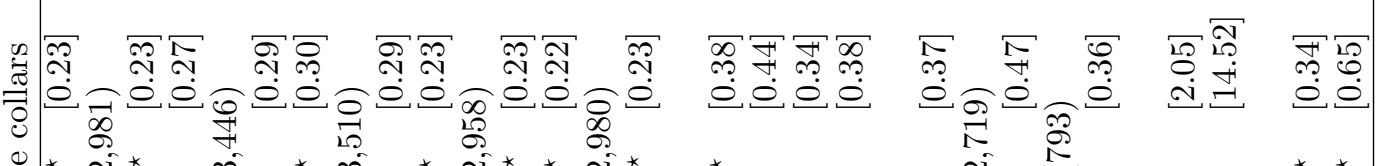

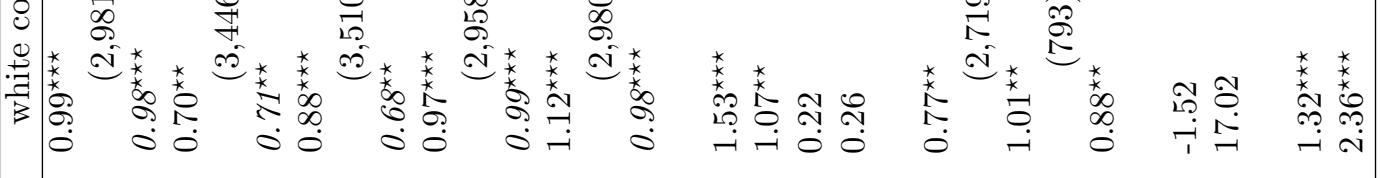

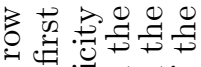

程 0

递

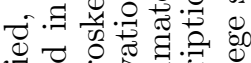

㺃

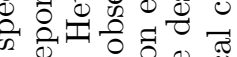
管 鸪

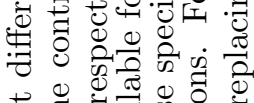
to

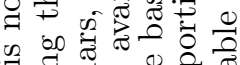
ㄴ. 헝 5. 证

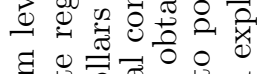

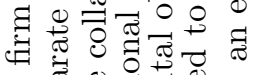

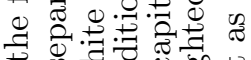
屯 0

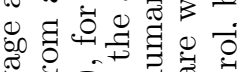

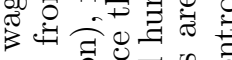

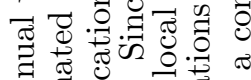

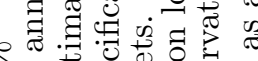
Os t)

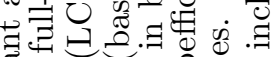

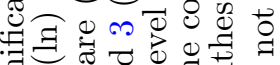

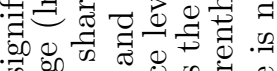

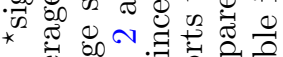

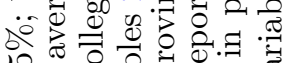

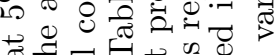

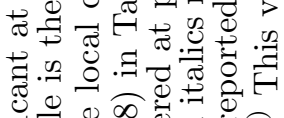
政 to에 *

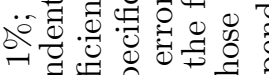
两

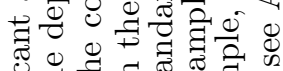

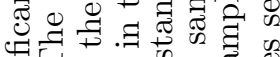
ton

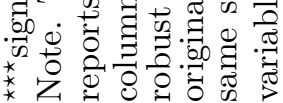




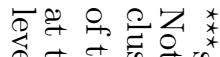

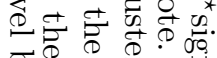

节寻莣. औ 8
$\square$
0
0

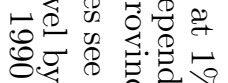

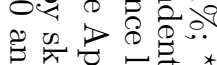

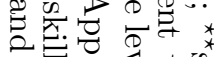

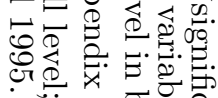
Q? ? $F$ 这通的 फ.

है

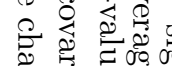
究

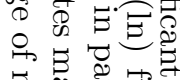

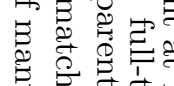

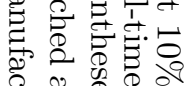

过

苛.

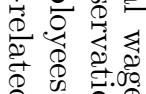

2.

छ.

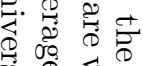

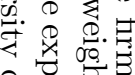

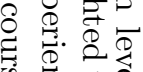

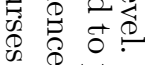

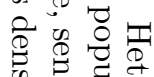

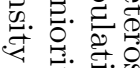

ชิ

๑气

की

仓

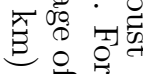

象索

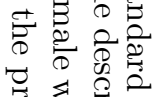

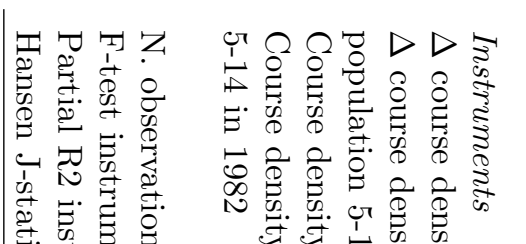

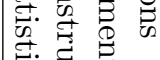

ते 䆑 龺

$\underset{\mathrm{C}}{\stackrel{8}{\mathrm{P}}}$

(

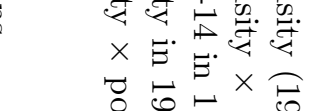

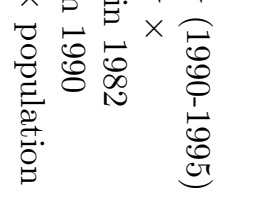

它

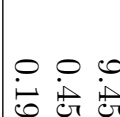

or or

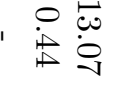

$\stackrel{0}{\circ}$

$\checkmark \mathrm{c}$

, $\stackrel{\circ}{\dot{0}}$

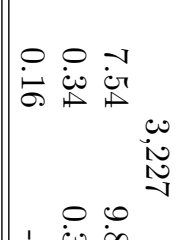

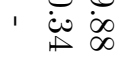

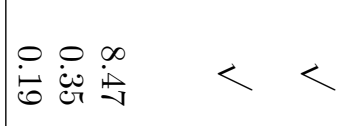

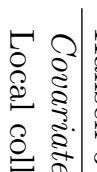

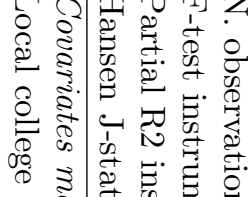

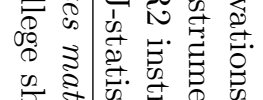

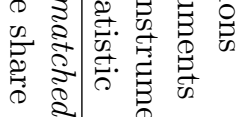

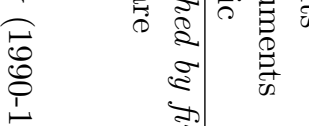

ב.

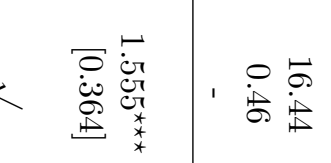

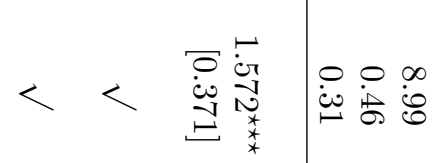

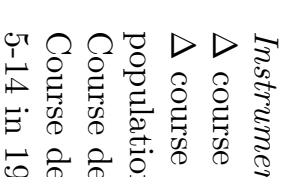

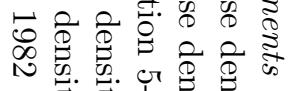

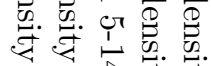

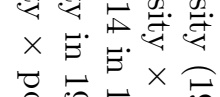

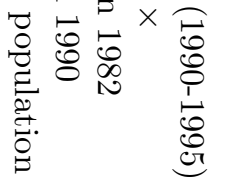

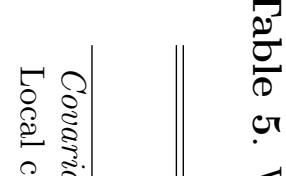

$\overbrace{\substack{0 \\ 0 \\ 0.0}}^{\circ}$

赵

के

ริ

హ)

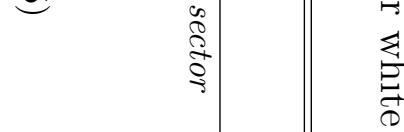

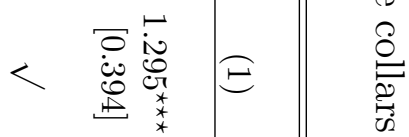

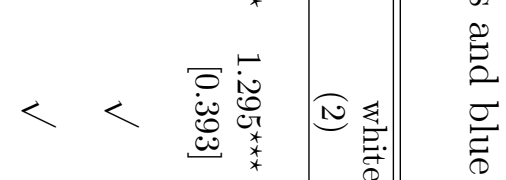

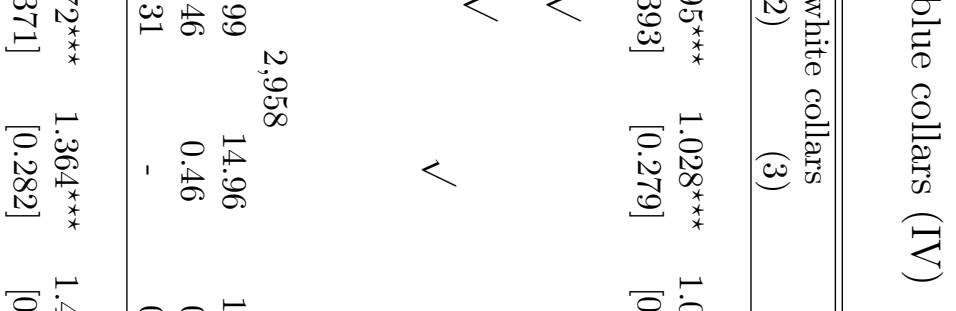

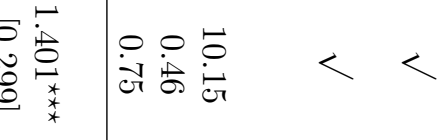

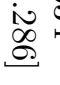

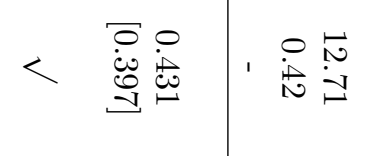

$<\quad$

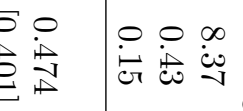

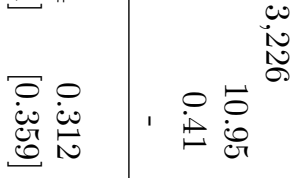

N

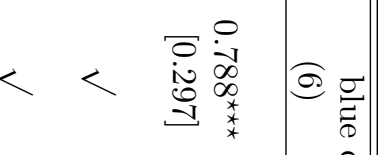

id

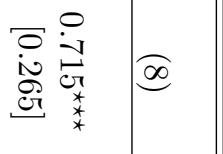

